\title{
Prevalence and Contamination Level of Staphylococcus aureus in Raw Camel Milk and Associated Risk Factors in Jigjiga District, Eastern Ethiopia
}

\author{
Biressaw Serda*, Asayegn Bekele and Daniel Abebe
}

College of Veterinary Medicine, Haramaya University, Haramaya, Ethiopia

"Corresponding author: Biressaw Serda, College of Veterinary Medicine, Haramaya University, Haramaya, Ethiopia, Tel: +251 911 052 265; E-mail: biressawserda2011@gmail.com

Rec date: November 12, 2017; Acc date: January 04, 2018; Pub date: January 05, 2018

Copyright: (c) 2018 Serda B, et al. This is an open-access article distributed under the terms of the Creative Commons Attribution License, which permits unrestricted use, distribution, and reproduction in any medium, provided the original author and source are credited.

\begin{abstract}
A cross sectional study was conducted from August, 2014 to February 2015 aimed to determine the prevalence of Staphylococcus aureus in raw camel milk and to assess risk factors. The study was conducted on a total of 384 bulk milk samples from three critical points. For this study both laboratory and questionnaire based data were collected. The overall prevalence of $S$. aureus was found to be $11.45 \%(44 / 384)$. The frequency of isolation of $S$. aureus varied between sources of sample and ranged from $7-15 \%$. The prevalence of $S$. aureus was $7.03 \%(9 / 128)$, $11.71 \%(15 / 128)$ and $15 \%(20 / 128)$ from household, primary collection centers and selling sites, respectively. The raw camel milk samples were contaminated and the $S$. aureus counts markedly variable among samples at different sampling points. Mean S. aureus count was found to be $4.2 \times 10^{4} \mathrm{CFU} / \mathrm{ml}$ and the mean count of the samples at household was $8.9 \times 10^{2} \mathrm{CFU} / \mathrm{ml}, 9.9 \times 10^{3} \mathrm{CFU} / \mathrm{ml}$ at primary collection centers and $1.1 \times 10^{5} \mathrm{CFU} / \mathrm{ml}$ at selling sites. The difference was not statistically significant between the sampling points ( $p>0.05)$. In the study area, camel milk is consumed $(100 \%)$ in its raw state without being subjected to any sort of processing treatment. The outcome of the present results suggests that, the examined raw camel milk samples were produced and handled under poor hygienic conditions with high health risk to the consumers. Consumption of raw camel milk should be of major concern from public health point of view. This study recommends for urgent development and adaptation of feasible and sustainable interventions to improve the camel milk hygiene and safety in study area and to mitigate staphylococcal food poisoning (SFP) in the region.
\end{abstract}

Keywords: Collection centers; Household; Jigjiga; Raw camel milk; Prevalence; Staphylococcus aureus

\section{Introduction}

Camel milk is one of the key foods available in arid and sub-arid regions where it covers a substantial part of the quantitative and qualitative nutritional needs. Because of its outstanding performance in the arid and semi-arid areas of eastern lowlands of Ethiopia where browse and water are limited, pastoralists rely mainly on camels for their livelihood [1]. Ethiopia possesses over 2.4 million dromedary camels that stand the country third in Africa in camel population [2]. Camels produce milk for quite longer period even during dry periods compared to cattle [3]. Dromedary camels are naturally browsers, thrive on sparse pasture and produce milk where other domesticated animals would virtually starve [4].

There are several constraints in camel milk production and marketing; clean water for washing containers is scarce or unavailable, common use of recycled oil plastic jerry-cans with small opening are very difficult to clean in pastoral areas and long durations during transportation in high ambient temperatures are among other factors [5]. Akweya et al. [6] observed that camels are usually milked in poor sanitary conditions, with all the predisposing factors to diseases such as mastitis that include dust, flies and scarce water resources.

SFP is often associated with the ingestion of manually handled foods that contain one or more highly heat stable staphylococcal enterotoxins $[7,8]$. Staphylococcus aureus species are prevalent food- borne bacterial pathogens that cause food poisoning in humans when ingested with contaminated foods [9].

The safety of milk with respect to food borne diseases is of great concern around the world. This is especially true in developing countries like Ethiopia where production of milk often takes place under unsanitary conditions and the consumption of raw milk is a common practice [10]. Nowadays, public health concern associated with microbial food safety has arisen [11]. In the last few decades, SFP has been reported as third cause of food-borne illnesses in the world. Among the foods implicated in SFP, milk, dairy products and meats, particularly handled foods, play a vital role since enterotoxigenic strains of $S$. aureus have been commonly isolated in them [12]. It has always been considered as one of the main causes of food poisoning [13].

Nonetheless, camel milk is produced in a traditional way, and is usually collected, handled and transported in poor sanitary conditions. Moreover, camel herds rarely benefit from veterinary care and, hence, mastitis diseases are common among lactating females. Therefore, the milk produced is likely to cause foodborne diseases and the natural antimicrobial factors can only provide a limited protection against specific pathogens and for a short period. Such risk is higher when the milk is consumed in its raw state as is commonly practiced by the local producers [14].

In spite of the aforementioned prevailing situation and the presence of a number of public health problems resulting from the consumption of raw milk, there is paucity of well documented information on the 
occurrence of Staphylococcus in raw camel milk in Ethiopia. Although $S$. aureus is a well-known bacterial pathogen in human and animal infections, little information is available at present about the occurrence and the toxicogenic potential of this bacterial species in camel milk and about the role raw camel milk might play in intoxication of the consumer by staphylococcal enterotoxins. Thus, this study is aimed to:

Isolate Staphylococcus aureus and estimate its prevalence from raw camel milk and determine level of contamination by CFU/ML.

Assess the knowledge, attitudes and hygienic practices of the pastoral community towards consumption and handling of raw camel milk.

\section{Materials and Methods}

\section{Study area}

The study was conducted in Jigjiga District, Somali regional state from August 2014 to February 2015. Jigjiga District is one of the six administrative Districts of the Jigjiga Zone which is situated in the Eastern part of Ethiopia about $635 \mathrm{~km}$ East of Addis Ababa at a latitude of $9^{\circ} 21^{\prime} \mathrm{N}$ and longitude of $42^{\circ} 48^{\prime} \mathrm{E}$. Temperature of the district is generally high all the year round where the mean minimum and maximum temperatures are around $20^{\circ} \mathrm{C}$ and $35^{\circ} \mathrm{C}$, respectively. The mean annual rain fall is ranging from 300 to $600 \mathrm{~mm}$ per annum and bimodal. The rainfall condition in the district is generally low, unreliable and with uneven distribution with sparsely distributed vegetation dominated by Cactus and Acacia species and bushy woodlands. The altitude ranges from 500 to $1500 \mathrm{~m}$ above sea level $[15,16]$ (Figure 1).

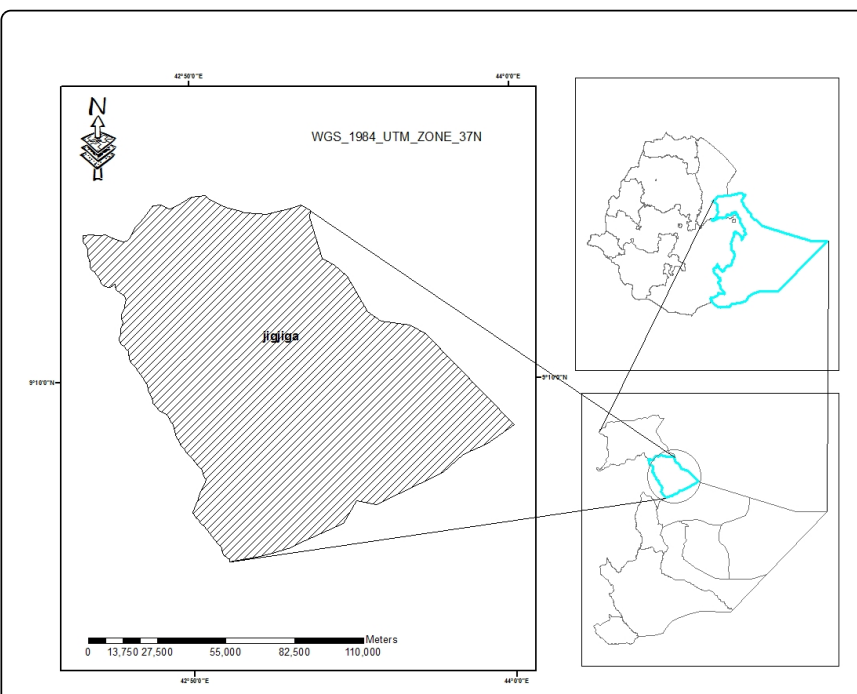

Figure 1: Map of study area.

\section{Study design and sampling}

A cross-sectional study was conducted from August 2014 to February 2015. Data were collected in two ways; laboratory and questionnaire interview. Since the prevalence of the selected bacteria is not known in the study area, the sample size was determined based on the expected prevalence of $50 \%$ using the formula given by Thrusfield,
[17] with 95\% confidence interval (CI) and 5\% desired absolute precision. A total of 384 raw camel milk samples were collected using random sampling. $25 \mathrm{ml}$ of bulk milk samples were taken from three critical points which are supposed to be the major risk areas for the consumers as many people may share the pooled product. The samples were collected in labeled sterile test tubes, aseptically packed and transported to the Veterinary microbiology laboratory of Haramaya University for analysis using an ice box. The examination of milk was performed immediately but if there was delay in examination, it has been kept in refrigerator at $40^{\circ} \mathrm{C}$. In addition to microbiological analysis of the raw milk, a total of 60 respondents comprising of milkers, camel milk sellers and consumers at different sites in the district were interviewed to gather information about the hygienic practices during milking, handling, storage, transportation and general the attitude and practices of the consumers towards consumption of raw camel milk.

\section{Laboratory analysis of raw camel milk}

Milk samples $(25 \mathrm{ml})$ were diluted in buffered peptone water $(225$ $\mathrm{ml}, 0.5 \% \mathrm{w} / \mathrm{v}$; peptone; $0.85 \% \mathrm{w} / \mathrm{v} ; \mathrm{NaCl}$ ) in a flask to make $10^{-1}$ dilution from which was produced decimal dilutions of up to $10^{-5}$. One milliliter of each dilution was inoculated and spread on surface of Mannitol Salt Agar using sterile bent glass rod and incubated at $37^{\circ} \mathrm{C}$ for $48 \mathrm{hr}$ to observe its ability to ferment mannitol and produce yellow halos. Plates containing 20-200 presumptive staphylococcal colonies were used for determining $S$. aureus count per milliliter of sample. For confirmation of $S$. aureus, presumptive colonies were picked up and were subjected to gram's stain and observed under microscope for gram's reaction, size, and shape and cell arrangements. Pure culture of the isolates was picked using a sterile loop and tested for catalase on sterile glass slides. The tube coagulase test was also performed on selected isolates of Staphylococcus grown on Tryptone Soya Broth (TSB). For final confirmation suspected culture was inoculated on Purple Agar Base (PAB) media plate with $1 \%$ of maltose and Blood Agar Plate (BAP) with 5\% sheep blood. The identification was based on the fact that $S$. aureus rapidly ferment maltose sugar in the basal medium and turns the medium and colonies to yellow and examined for the haemolytic pattern on the surface of BAP, Beta ( $($ ) hemolysis 1 $[18,19]$.

\section{Data analysis}

All data obtained from laboratory analysis and questionnaire survey were coded and entered in to Epi-info and exported to SPSS version 20 for descriptive analysis. Difference among and between proportions of the groups with certain determinant factors was determined by chisquare $\left(\chi^{2}\right)$ test. A p-value $<0.05$ was considered indicative of a statistical significant difference. The differences among means of the parameters was tested by a T-test to observe the variations due to state of hygienic practice, duration of transportation and storage, and knowledge of pastoralists.

\section{Results and Discussion}

\section{Prevalence of Staphylococcus aureus in raw camel milk}

The overall prevalence of $S$. aureus in the study area was found to be $11.45 \%(44 / 384)$ which varied between sources of sample and ranged from $7-15 \%$ (Table 1). The result showed a slight difference in prevalence among the three-sampling point along the market chain 
although difference was not statistically significant $(\mathrm{p}>0.05)$. This could be attributed to the cumulative effects of milk contamination at different critical points. Additionally, handling of milk in different plastic containers and the use of unclean water for washing of milking equipment may cause contamination of milk. Similarly, Rahimi and Alian, [20] in Iran, Birhanu et al. [21] in north eastern Ethiopia, Shuiep et al. [22] in Sudan and Aydin et al. [23] in Turkey reported 11.0\%, $7.14 \%, 8.8 \%$ and $10.2 \%$, respectively.

Although many authors described the ability of camel milk to inhibit the growth of many bacterial species due to the lytic action of lysozyme and lactoferrin contained in camel milk [24,25], camel milk still represents a significant source of infection for human [11,26,27]. The prevalence of $S$. aureus isolates found in raw camel milk samples in the present study represents a poor quality and public health risk to the consumer.

\begin{tabular}{|l|l|l|}
\hline Sampling points & No Examined & $\begin{array}{l}\text { Number positive } \\
\text { prevalence (\%) }\end{array}$ \\
\hline Households & 128 & $9(7.03)$ \\
\hline Collection centers & 128 & $15(11.71)$ \\
\hline Selling sites & 128 & $20(15.62)$ \\
\hline Total & 384 & $44(11.45)$ \\
\hline
\end{tabular}

${ }^{*}$ Chi-square $\left(X^{2}\right)=0.097$

Table 1: Prevalence of $S$. aureus in raw camel milk at different sampling points in Jigjiga district (2015).

\section{Enumeration of Staphylococcus aureus}

The mean S. aurues count of the three sampling points was found to be $4.2 \times 10^{4} \mathrm{CFU} / \mathrm{ml}$ and the mean count of the samples at household was $8.9 \times 10^{2} \mathrm{CFU} / \mathrm{ml}, 9.9 \times 10^{3} \mathrm{CFU} / \mathrm{ml}$ at primary collection centers and $1.1 \times 10^{5} \mathrm{CFU} / \mathrm{ml}$ at selling sites. The analyzed samples were generally contaminated and the microbial counts markedly variable among samples at different sampling points (Table 2).

The $S$. aureus counts were increasing along the marketing chain. Camels' milk at household level had a range of count $4.2 \times 10^{1}$ to $9.5 \times$ $10^{2} \mathrm{CFU} / \mathrm{ml}$. Bulk milk at the primary collection centers had $8.9 \times 10^{2}$ to $1.3 \times 10^{3} \mathrm{CFU} / \mathrm{ml}$ and at final market had $8.7 \times 10^{3}$ to $1.5 \times 10^{5}$ $\mathrm{CFU} / \mathrm{ml}$. This difference in count depends on several parameters such as the milk itself, contamination of the camel's udder, hygienic handling of milking/sellers personnel and other considerations such as transportation and containers.

\begin{tabular}{|l|l|l|}
\hline Sampling point & Range of counts cfu/ml & Averages of cfu/ml \\
\hline Household & $4.2 \times 10^{1} \_9.5 \times 10^{2}$ & $8.9 \times 10^{2}$ \\
\hline Collection centers & $8.9 \times 10^{2}-1.3 \times 10^{3}$ & $9.9 \times 10^{3}$ \\
\hline Selling sites & $8.7 \times 10^{3}-1.5 \times 10^{5}$ & $1.1 \times 10^{5}$ \\
\hline Over all & $4.2 \times 10^{1}-1.5 \times 10^{5}$ & $4.2 \times 10^{4}$ \\
\hline
\end{tabular}

Table 2: Averages count of $S$. aureus in raw camel milk at three sampling points in Jigjiga district (2015).
The results of mean count of $S$. aureus in this study was in agreement with reports from Algeria, Kenya, Saudi Arabia and Morocco for tests on camel milk samples [11,14,27,28] with the mean count of $4.5 \times 10^{4} \mathrm{CFU} / \mathrm{ml}, 10^{4}, 2.7 \times 10^{4} \mathrm{CFU} / \mathrm{ml}$ and $1.3 \times 10^{5}$, respectively. Typically, doses of SE that cause illness result when at least $10^{5}-10^{8} \mathrm{CFU} / \mathrm{ml}$ of $S$. aureus are present $[29,30]$. A high count of $S$. aureus reaching up to $10^{5}$ in this study presents a potential health hazard particularly for the presence of enterotoxins. It is worth to mention that there are no microbiological standards concerning camel milk. Therefore, the microbiological limit values for cow milk were used to assess the quality of camel milk.

Neither the absence of $S$. aureus nor the presence of small numbers of organism can provide complete assurance that the milk is safe, since conditions inimical to the survival of $S$. aureus may result in a diminished population or death of viable microbial cells, while sufficient toxins remain to elicit symptoms of staphylococcal food poisoning [31].

\section{Owners sanitary knowledge, attitude and practices on milk handling and consumption}

A total of 60 respondents comprising of milkers, camel milk sellers and consumers at different site in the district were selected and interviewed. From the total respondents 38(63.33\%) were female and $22(36.66 \%)$ were male and their educational statuses were $33(55 \%)$ illiterate, 22(36.66\%) elementary class and 7(11.66\%) were high school class. Majority of camel milkers interviewed $(80 \%)$, reported that they do not practice washing their hand prior to milking. More than $95 \%$ of the respondents indicated that while preparing utensils for milking they wash and smoke milking utensils with wood called Oliva africana which is locally called "Ugay" before milking camels and they explained that this keeps milk for longer period of time. Teats of milking camels were not washed before milking, as the pastoralists believed that camel milk is always clean (Table 3). Milk collected in such a way is likely to cause foodborne illness that originate from staphylococcal enterotoxins.

Camel milk is consumed (100\%) in its raw state without being subjected to any sort of processing treatment. This observation is in agreement with that reported earlier by Eyassu [32], Farah et al. [33] and Alhadrami [34] who indicated that camel milk is consumed fresh in most camel rearing societies. Consumption of raw camel milk should be of major concern from public health point of view. Higher levels of $S$. aureus count were detected in raw camel milk and this suggests the potential hazard associated with consumption of raw camel milk [14].

\begin{tabular}{|l|l|}
\hline Conditions & $\begin{array}{l}\text { Number and proportion (\%) of } \\
\text { responses }\end{array}$ \\
\hline Smoking of milking equipments & \\
\hline No & $1(5 \%)$ \\
\hline Yes & $19(95 \%)$ \\
\hline Hand washing & \\
\hline No & $16(80 \%)$ \\
\hline Yes & $4(20 \%)$ \\
\hline Cleaning milking equipment & \\
\hline
\end{tabular}




\begin{tabular}{|l|l|}
\hline Once per day & $16(80 \%)$ \\
\hline Twice per day & $3(15 \%)$ \\
\hline Once a week & $1(5 \%)$ \\
\hline Teat washing & \\
\hline No & $13(65 \%)$ \\
\hline Yes cleaning & $7(35 \%)$ \\
\hline $\begin{array}{l}\text { Use of warm water for } \\
\text { equipt's }\end{array}$ & $18(90 \%)$ \\
\hline No & $2(10 \%)$ \\
\hline Yes & $14(70 \%)$ \\
\hline Soap use & $6(30 \%)$ \\
\hline No & $16(70 \%)$ \\
\hline Yes & $5(25 \%)$ \\
\hline Condition for consumption & $1(5 \%)$ \\
\hline Raw & $20(100 \%)$ \\
\hline Believe in medicinal values & \\
\hline Yes & $20(100 \%)$ \\
\hline Quality judgment & \\
\hline Taste & \\
\hline Color & \\
\hline Odour & \\
\hline Disease history following Consumption & \\
\hline No & \\
\hline Yes & \\
\hline Hospitalization & \\
\hline No & \\
\hline Yes & \\
\hline
\end{tabular}

milk than mastitis bacteria [5]. The following list of milk hygiene risk factors (Table 4) is based on the current practices of Somali milk producers/traders.

\begin{tabular}{|l|l|}
\hline $\begin{array}{l}\text { Camel milk production and } \\
\text { marketing chain }\end{array}$ & Milk hygiene risk factors \\
\hline Milking & $\begin{array}{l}\text { Unclean udder, unclean hands, unclean } \\
\text { (plastic) milking bucket, unclean storage } \\
\text { container (plastic) }\end{array}$ \\
\hline Primary milk collection & Unclean (plastic) transport container \\
\hline Transportation & Delayed transport \\
\hline Consumer & $\begin{array}{l}\text { Traditional preference for consumption of raw } \\
\text { milk }\end{array}$ \\
\hline
\end{tabular}

Table 4: Camel milk hygiene risk factors along production and marketing chain in Jigjiga district, eastern Ethiopia (2015).

\section{Conclusion and Recommendations}

The presence of $S$. aureus in raw milk samples analyzed in this study can be a risk to human health, causing a public health problem, as this bacterium produces toxins that cause toxic food infections. The presence of $S$. aureus and counts above $10^{4} \mathrm{CFU} / \mathrm{ml}$ shows up unsanitary conditions in the camel milk. This may increase the risk of staphylococcal toxin production more resistant to the heating process. The examined raw camel milk samples were produced and handled under poor hygienic conditions with high health risk to the consumers. Staphylococcus aureus isolates found in raw camel milk samples in the present study represents a poor quality and public health risk to the consumer.

Thus, we recommend large-scale research regarding the quality of raw camel milk, milking protocols and sanitizing programs should be conducted to understand the behavioral risk factors associated with raw milk production, consumption and that educational programs will be developed to address issues connected to consumption of raw camel milk. Raw camel milk intended for human consumption must be subjected to pasteurization or heat treatment at least equivalent to pasteurization temperature in order to guarantee the quality of these highly popular products in Jigjiga district to decrease the risk of staphylococcal food poisoning. Furthermore, public education should be given to improve their awareness about the importance of proper herd health management and hygienic milk handling practices from cow udder to table in order to minimize the adverse effect of zoonotic pathogens.

Jigjiga district $(\mathrm{n}=20)(2015)$.

Pastoralists claim that camel milk is superior to the milk of other species. They gave many reasons for their preference of camel milk to milk of other domestic animals. Unlike cows' milk, camel milk has medicinal values and can be used to treat a number of aliments in human beings. According to the pastoralists view, the claimed therapeutic property of camel milk is attributed to the fact that camels browse on various plant species and active agents with therapeutic properties from these plant species are secreted into the milk of camels. Women are generally responsible for marketing of camel milk in the study area. This is in agreement with a report by Eyassu [32] who indicated that women are responsible for processing and marketing of camel milk in Somalia.

Under pastoral production conditions, environmental contamination is likely to play a bigger role in the hygiene of raw camel

\section{References}

1. Bekele T, Molla B (2002) Mastitis in lactating Camels (Camelus dromedarius) in Afar Region, North eastern Ethiopia. Berl Munch Tierarztl Wochenschr 114: 169-172.

2. Food and Agricultural Organization of US (FAO) (2010) Production year book, Vol. 56. Rome: Food and Agriculture Organization of the United Nations (FAO), p: 432.

3. Kurtu MY (2003) Certain aspects of the Dairy system in the Harar milk shed, Eastern Ethiopia. PhD. Thesis, School of Graduate Studies of the Universities of the Free State, South Africa.

4. Zubeir E, Ibtisam EM, Ehsan M (2010) Studies on camel management practice and constraints in pre-urban areas of Khartoum State, Sudan. Int J Dairy Sci 5: 276-284. 
5. Younan M (2004) Milk Hygiene and Udder Health. In: Farah Z, Fischer A (eds). Milk and meat from the camel-Handbook on products and processing, Switzerland: Vdf Hochschul verlagan der ETH Zürich, pp: 67-76.

6. Akweya BA, Gitao CG, Okoth MW (2010) The prevalence of common milk pathogens and antibiotic resistance of the organisms in camel milk from North Eastern Province of Kenya. International Camel Symposium, Garissa, June 7th-11th 2010, Kenya.

7. Vanegas MC, Vasquez E, Marthinez AJ, Rueda AM (2009) Detection of Listeria monocytogenes in raw whole milk for human consumption in Colombia by real time PCR. Food Control 20: 430-432.

8. Smith K (2007) Food borne pathogenic microorganisms and natural toxins. Food Drug Administration Center Food Safety Applied Nutrition 10: 119-150.

9. Salandra G, Goffredo E, Pedarra C, Nardella M, Parisi A (2008) Occurrence, characterization and antimicrobial resistance pattern of Staphylococcus species isolated from dairy products in southern Italy. Int J Food Microbiol 9: 327-360.

10. Wubete A (2004) Bacteriological quality of bovine milk in small holder dairy farms in Debre Zeit, Ethiopia. MSc. Thesis, Faculty of Veterinary Medicine, Addis Ababa University.

11. El-Ziney MG, Al-Turki AI (2007) Microbiological quality and safety assessment of camel milk (Camelus dromedarius) in Saudi Arabia (Qassim Region). Appl Ecol Environ Res 5: 115-122.

12. Ateba C, Mbewe M, Moneoang MS, Bezuidenhout CC (2010) Antibioticresistant Staphylococcus aureus isolated from milk in the Mafikeng Area, North West province, South Africa. South Afr J Sci 106: 12-13.

13. Gran HM, Mutukumina AN, Wethlesen A, Narvhus JA (2002) Smallholder dairy processing in Zimbabwe: the production of fermented milk products with particular emphasis on sanitation and microbiological quality. Food Control 13: 161-168.

14. Benkerroum N, Boughdadi A, Bennani N, Hidane, K (2003) Microbiological quality assessment of Moroccan camel milk and identification of predominating lactic acid bacteria. World J Microbiol Biotechnol 14: 645-648.

15. Ministry of Agriculture and Rural Development (MOARD-PADS) (2004) Federal Democratic Republic of Ethiopia Ministry of Agriculture and Rural Development. Pastoral Areas Development Study MOARD-PADS livestock resources study 8, livestock production and marketing TECHNIPLAN in association with MCE, Agri. studio, Addis Ababa and Rome.

16. Central Statistical Authority of Ethiopia (CSA) (2009) Agricultural Sample Survey. Report on Area and Production - Somali Region. Version 1.1 - 26 January 2009.

17. Thrusfield MV (2005) Veterinary Epidemiology 3rd edn. Oxford, England: Blackwell Science, Ltd.

18. Quinn JP, Carter EM, Merkey B, Carter RG (1999) Clinical veteran LIMI Microbiology. Edinburgh London, New York: Elsevier Limited.
19. Ciira K (2003) Laboratory manual of Food Microbiology for Ethiopian health and Nutrition Research Institute. (Food microbiology laboratory) UNIDO PROJECT (ya/eth/03/436/11-52).

20. Rahimi E, Alian F (2013) Presence of enterotoxigenic Staphylococcus aureus in cow, camel, sheep, goat, and buffalo bulk tank milk. Vet Arch 83: 23-30.

21. Birhanu H, Etsay K, Hailay K (2008) Assessment of bacteriological quality of raw camels' milk in Ab -Ala, north eastern Ethiopia. Livest Res Rural Dev 20: 27-35.

22. Shuiep ES, Kanbar T, Eissa N, Alber J, Lämmler C, et al. (2009) Phenotypic and genotypic characterization of Staphylococcus aureus isolated from raw camel milk samples. Res Vet Sci 86: 211-215.

23. Aydin A, Sudagidan M, Muratoglu K (2011) Prevalence of staphylococcal enterotoxins, toxin genes and genetic relatedness of foodborne Staphylococcus aureus strains isolated in the Marmara region of Turkey. Int J Food Microbiol 148: 99-106.

24. Wernery U (2003) New Observations on Camels and their Milk, Dar Al Fajr pub. Abu Dhabi, United Arab Emirates, pp: 41-42.

25. Elagamy EI, Ruppanner R, Ismail A, Champagene CP, Assaf R (1992) Antimicrobial and antiviral activity of camel milk protective proteins. J Dairy Res 59: 169-175.

26. Matofari JW, Shalo PL, Younan M, Nanua NJ, Adongo A, et al. (2013) Analysis of microbial quality and safety of camel (Camelus dromedarius) milk chain and implications in Kenya. J Agricult Extens Rural Dev 5: 50-54.

27. Benyagoub E, Ayat M, Dahan T, Smahi K (2013) Level of control of the hygienic quality of camel milk (dromedaries dromedarius) in south west Algeria and its impact on security. J Food Sci Technol 1: 53-60.

28. Mulwa K, Kaindi DW, Esther S, John W, Jasper K, et al. (2011) Microbiological Quality of Raw Camel Milk across the Kenyan Market Chain. Global Science Books 5: 79-83.

29. Seo KS, Bohach GA (2007) Staphylococcus aureus. In: Doyle, MP, Beuchat LR (eds.) Food microbiology: Fundamentals and frontiers. ASM Press, Washington DC, pp: 493-518.

30. Montville TJ, Matthews KR (2008) Food microbiology: An Introduction. 2nd edn, ASM Press, Washington DC. Pp: 105-112.

31. Bennett RW, Monday SR (2003) Staphylococcus aureus. In: Miliotis MD, Bier JW (eds.) International handbook of food borne pathogens, New York, Marcel Dekker, pp: 240-258.

32. Eyassu S (2007) Handling, preservation and utilization of camel milk and camel milk products in Shinile and Jijiga Zones, eastern Ethiopia. Livest Res Rural Dev 19: 26-35.

33. Farah Z, Mollet M, Younan M Dahi R (2007) Camel dairy in Somalia: Limiting factors and development potential. Livest Sci 110: 187-191.

34. Alhadrami GA (2003) Camel. In: Roginski H, Fuquay JW, Fox PF (eds.) Encyclopedia of Dairy Sciences, Amsterdam: Academic Press, pp: 616-623. 